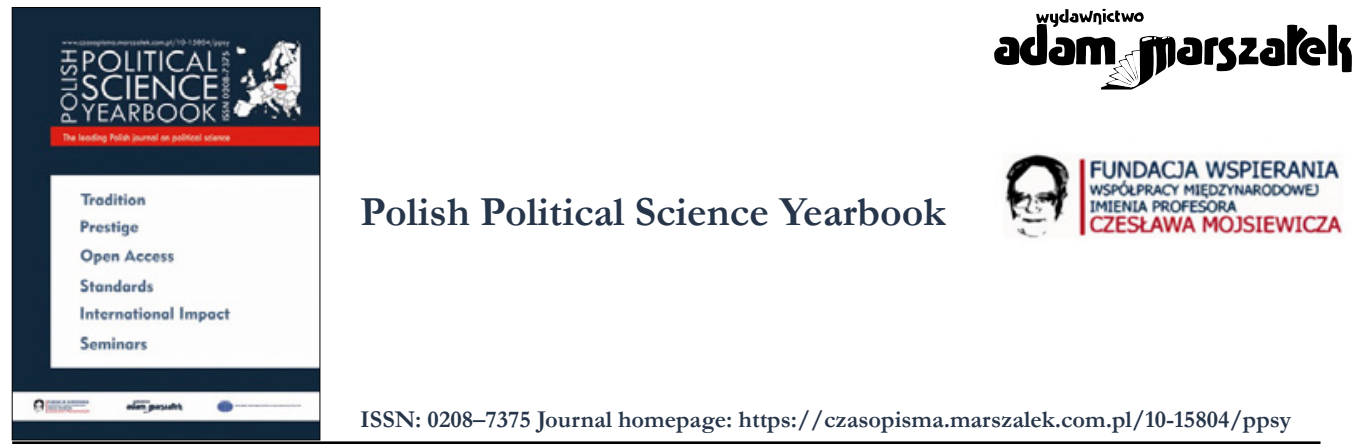

\title{
The Round Table in 1989 - Consequences and Evaluation
}

\section{Wojciech Polak ${ }^{1}$, Sylwia Galij-Skarbińska ${ }^{2}$}

ORCID: 0000-0002-6069-2876, $0000-0003-1799-4243^{2}$

To cite this article please include the following information:

- Journal title: Polish Political Science Yearbook

- Volume number: 50

- Year of publication: 2021

- Published ahead-of-print

Example styles:

[APA Style]: Polak, W., \& Galij-Skarbińska, S. (2021). The Round Table in 1989 - Consequences and Evaluation. Polish Political Science Yearbook, 50 (issue number), pages. https://doi. org/10.15804/ppsy202131

[Chicago Style]: Wojciech Polak, Sylwia Galij-Skarbińska, “The Round Table in 1989 - Consequences and Evaluation” Polish Political Science Yearbook 50, no. [issue number] (2021).

To link to this article: https://doi.org/10.15804/ppsy202131

Published ahead-of-print

Final submission: 28 June 2021

Published online: 10 July 2021

Printed issue: December 2021

Submit your article to PPSY 


\title{
Wojciech Polak
}

Nicolaus Copernicus University (Poland)

ORCID: 0000-0002-6069-2876

e-mail: wp@umk.pl

\section{Sylwia Galij-Skarbińska}

Nicolaus Copernicus University (Poland)

ORCID: 0000-0003-1799-4243

e-mail: sgs@umk.pl

\section{The Round Table in 1989 - Consequences and Evaluation}

\begin{abstract}
The agreement of the round table signed on April 5, 1989, resulted in the creation of the government of Tadeusz Mazowiecki (September 12,1989) and the end of communist rule in Poland. However, it should be pointed out that the agreement of the round table is currently often criticized. It is claimed, among other things, that the agreement was a form of "unification of the elite" (the term Jack Kuroń) to obtain financial and political benefits. As a result, the mixed communist-solidarity elite has taken over power in the country, guided solely by their own interests. It is also stressed that the contract has enabled the Communists to retain enormous influence in the special services, state administration, various institutions, the economy, and finance. On the other hand, these irregularities have been attributed to the solidarity elites who consider the round table agreements to be persistent. Other parts of the solidarity elite treated the round table exclusively as tactical action to take power away from the Communists.
\end{abstract}

Keywords: "Solidarność", round table, contracted elections in Poland, Tadeusz Mazowiecki cabinet

\section{Introduction}

In a situation of the aggravating economic and political crisis and increasing social unrest, demonstrations, and strikes, secret meetings between representatives of the underground "Solidarność" and the government took place in August 1988. A round table concept emerged, which was to lead to a compromise between the government and at least a particular part of 
the opposition. This article focuses on the circumstances and political consequences of the agreements between the government and the opposition in the spring of 1989. The attitude of various circles of the Solidarity opposition to the ongoing political changes implied by the round table contract was also discussed.

On August 31, 1988, Lech Wałęsa met with General Czesław Kiszczak. Since September 15,1988 , the talks had been held in a larger group. However, the government was incredibly unwilling to legalize "Solidarność, and despite a compromising attitude of the union delegation, the negotiations reached an impasse. Meanwhile, the government was changed spectacularly. Mieczysław Rakowski replaced Zbigniew Messner as a prime minister (on September 27, 1988). On October 29, 1988, Mieczysław Wilczek, the Minister of Industry, signed a document on the liquidation of the Gdańsk shipyard. That led to the breakdown of the talks. The authorities restarted brutal actions, like dispersal of demonstrations organized in Gdańsk, Katowice, and Poznań on November 11, 1988. Through the mediation of Bishop Bronisław Dąbrowski, another meeting of Lech Wałęsa with Czesław Kiszczak took place on November 12,1988. It did not result in any solutions; furthermore, the authorities sent the already constructed round table to a warehouse. Alfred Miodowicz, the chairman of the All-Poland Alliance of Trade Unions and a firm opponent of "Solidarność", contributed to the breaking of that impasse with his, possibly not very well-considered, gesture. He proposed to Lech Wałęsa a television debate, and this backed the management of the Polish United Workers' Party (PZPR) with Wojciech Jaruzelski at its head (unwilling to legitimize Wałęsa by showing him on television) into a corner. The debate was held on November 30, 1988, and in the opinion of the majority of viewers ended with Lech Wałęsa's victory (Dudek, 2002, pp. 20-28; Roszkowski, 2001, pp. 402-403; Holzer \& Leski, 1990, pp. 156-167).

The debate between Wałęsa and Miodowicz, as well as Wałęsa's visit to France in December, where he was met with enthusiasm and the greatest honors, prompted the PZPR leadership to a concession in the case of "Solidarność" legalization. This decision was made at the $10^{\text {th }}$ Plenum of the PZPR Central Committee, debating in two rounds: December 20-21, 1988, and January 16-18, 1989. On January 27, 1989, during a meeting of Lech Wałęsa and Czesław Kiszczak, all issues related to the round table talks were agreed upon. Earlier, on December 18, 1988, Lech Wałęsa appointed the Citizens' Committee with the NSZZ "Solidarność" Chairman, consisting of 135 members. Many committee members supported the compromise with the PRL authorities, and this was supposed to facilitate the round table talks (Dudek, 2002, pp. 28-32; Polak, 2003, p. 545).

\section{Round Table Agreement}

The "round table" talks started on February 6, 1989, and were held till April 5, 1989. In total, 452 people participated in them. However, the most important decisions were made by a group of several people. While there were no significant controversies concerning the legalization of "Solidarność" and "Solidarność RI" (registered on April 20, 1989), the issue 
of political reforms led to many disputes. Eventually, following secret talks in Magdalenka, in which Lech Wałęsa and Czesław Kiszczak participated, it was decided that the government party would have guaranteed $65 \%$ of seats in the parliament elections. They were to be granted to members of PZPR, the United People's Party (ZSL), the Alliance of Democrats (SD), the PAX Association, the Polish Catholic and the Social Association, and the Christian and Social Union. Furthermore, non-party candidates could fight for 35\% of seats in the free elections. The authorities also agreed to the formation of the second house of the Parliament, the Senate, with one hundred seats, and elections to this house also were to be free. It was decided that both houses (the National Assembly) would elect a president with extensive competences during a joint seating. The final official meeting of the round table took place on April 5, 1989. The Sejm adopted all agreed political changes at an express pace on April 7, 1989, similarly as an amendment to the Trade Unions Act, recognizing the pluralism of trade unions. At the same sitting, the liberal "Associations Law" was passed. Following the Council of State decision, the first round of the elections was to be held on June 4, 1989, and the second round on June 18, 1989. The majority of MPs (425) were to be elected in multi-member constituencies. In each constituency, seats were assigned to the government coalition and non-party candidates. The remaining 35 seats were allocated to the so-called national list, assigned as a whole to the government coalition (Dudek, 2002, pp. 32-34; Polak, 2003, p. 548).

\section{Around the June Elections. Political Consequences of the Contract}

The election campaign started in April was organized very efficiently by "Solidarność" people. On the national level, it was officially initiated in Gdańsk on April 29, 1989. Then, all candidates had their photographs taken with Lech Wałęsa. This proved to be an effective propaganda move ("Kalendarium", p. 350; Przeglad Pomorski, 1989, May). The elections on June 4, 1989, went relatively smoothly. They were not only an act of voting that was already partly free (as it was joked, in 35\%). In fact, it was also a referendum of the society, in which the period of the Communist ruling was evaluated. One did not have to be a perceptive observer to be convinced about the landslide victory for "Solidarność". Consequently, "Solidarność" got 92 seats out of 100 possible in the Senate and 160 seats of 161 possible in the Sejm. Only two candidates from the national list won seats, and special regulations were required to fill that list in the second round. The said second round on June 18, 1989, confirmed that victory. All non-party seats in the Sejm and 99 out of 100 seats in the Senate were won by "Solidarność" (Dudek, 2002, pp. 58-61; Dudek, 2000). Members of Parliament and Senators from "Solidarność" formed the Citizens' Parliamentary Club (OKP).

The ruling Communist elites were going through a crisis caused by a severe defeat of the national list, and the election results showed that the slow current of changes announced at the round table would accelerate. As Antoni Dudek writes, the Citizens' Club leaders were as surprised by the election results as the previous authorities (Dudek, 2007, pp. 40-41). It 
partly resulted from the fact that being used to strictly cabinet politics that they had been conducting in previous months, they were scared that the situation would go beyond the framework of the "round table" scenario, abolishing the achieved agreement and stopping further reforms (Michnik, 1989, June 6, p. 1). The election results stirred hopes of many people centered around "Solidarność" that the changes would accelerate. However, here the mechanism imposed by leaders of the "Solidarnośćc" side, expressed, amongst others, by Lech Wałęsa, Jacek Kuroń, Bronisław Geremek, and Tadeusz Mazowiecki, was put into operation. In the extended interview conducted by Jacek Żakowski, Bronisław Geremek directly said (Geremek \& Żakowski, 1990, p. 228):

Analyzing the situation at that time, we perceived the government as an armed nomenclature. We were afraid to provoke its physical reaction. We thought that taking over the government by us required time, needed by the people of nomenclature to become used to the thought of giving the power-up.

That attitude appeased the Communist government on the one hand, while on the other, it evoked many strong emotions among members of "Solidarność" and other organizations. For example, just after the end of the round table talks, Konrad Morawiecki, the leader of "Solidarność Walcząca", announced in the weekly "Solidarność Walcząca" (Morawiecki, 1989, pp. 1-2) that his organization would not participate in the elections and called for their boycott. ${ }^{1}$ Treating as the success the legalization of NSZZ "Solidarność" and the declaration of support for rules of the parliamentary democracy and market economy from the government party, Morawiecki prepared a long list of objections to the compromise concluded with the PRL authorities. He accused the "round table" opposition, for example, of the intent to reform the system instead of abolishing it completely and of the departure from the democratic ethos by accepting those pseudo elections, and objected to the "Solidarność" consent to granting to the ruling coalition the majority in the Sejm, as, in his opinion, it was a specific "legalization of the Communist usurpation of the leading role in Poland" ("Przegląd prasy opozycyjnej", p. 6).

Meanwhile, the wave of enthusiasm quickly brought subsequent changes and transfer of power to the "Solidarność" movement. A few days after the first round of the elections, negotiations were initiated with the authorities concerning the selection of candidates for the president and the prime minister. While for the Communists, the candidature of General Jaruzelski was evident, yet it was not so in the case of the opposition. In Lech Wałęsa's circles, informal talks concerning a potential future candidate had started, and the leader himself was perceived as one. However, according to Adam Michnik, he refused and named Bronisław Geremek for that position. It resulted in strong critical voices on the other side, or

1 “Solidarność Walcząca. Pismo Organizacji Solidarność Walcząca”, Grupa Zakładowa Stoczni im. Komuny Paryskiej. 
even blackmail, to which General Czesław Kiszczak resorted, directed against Archbishop Bronisław Dąbrowski, stating that a president from "Solidarność" would lead to the coup détat and prevent further reforms, destroying the already achieved compromise (Dudek, 2007, p. 43). Thus, for the first time, a clearly stated threat of using the special forces and the army appeared.

The leaders of the PZPR Central Committee did not accept the possibility of proposing a different candidate for the president or an appointment of the prime minister from "Solidarność". However, it was becoming clear that over 60 percent majority in the Sejm did not exist in practice. SD and ZSL, the two parties previously remaining under the PZPR influence, started to break out from this system, announcing that not all MPs would support General Jaruzelski.

At one moment, the general resigned from standing as a candidate, causing significant concern in the party. It happened during the $13^{\text {th }}$ Plenum of the PZPR Central Committee. However, it should be emphasized that for a part of "Solidarnośc", this decision was unexpected but advantageous. Wałęsa formally offered his support to the head of the Ministry of the Internal Affairs, promising that some MPs and senators would support him from OKP. This way, he counted on weakening the opponents, as he was aware that Kiszczak had less support in his party than Jaruzelski.

In fact, information emerged, relatively quickly taken up by the media, that PZPR was not unanimous on an issue of a candidate for the president. At that time, the article by Adam Michnik, "Wasz prezydent nasz premier" ("Your president, our prime minister") reverberated most strongly, as it led to confusion in the "Solidarność" circles and the opposite side alike (Michnik, 1989, July 3, p. 1).

In the interview for "Gazeta Wyborcza", Lech Wałęsa explained the decision of the Citizens' Parliamentary Club not to propose its own candidate for the president in the following way ("Lech Wałęsa dla Gazety Wyborczej”, p. 1):

The majority [of Western politicians] tells me: be careful - too fast, be careful - not this way, be careful - you cannot do everything. And there are also Western economists who actually say that they will give only when we take the government. In my opinion, we must go forward at a slightly slower pace, in a little bit wiser way, a bit more together, honestly and democratically.

So, we will have the Communist government and General Jaruzelski as a president [...] Now we will have our own group in the Sejm and the Senate that will take a closer look at those tabooed issues, so we will learn that one day.

Eventually, following many internal pressures and after obtaining a guarantee from ZSL and SD, Jaruzelski changed his mind and stood as a candidate in the elections. As it turned out on July 19,1989, those guarantees proved to be empty. General Jaruzelski was elected with a majority of one vote, mainly due to OKP MPs' efforts. 
The pre-election presidential crisis exposed ruling elites' decomposition, which meant that the road to the "Solidarność" government did not have to be closed. The negotiations concerning the shape of the future government continued, and the Communists did not want to give up their dominant position, proposing for OKP members solely and only less strategic ministries. Jaruzelski himself did not give up such intentions and using his presidential powers, he appointed General Czesław Kiszczak as the prime minister, entrusting him with a mission to form a new government. That caused a strong objection of Wałęsa, clearly expressed during his conversation with the president, when he handed a statement to Jaruzelski. He stated that "the only reasonable solution will be to transfer the power to these forces that are supported by the majority of the society" (Dudek, 2007, p. 49). That statement surprised PZPR activists, as they thought that Kiszczak, perceived as one of the architects of the round table, would be accepted by all Poles with understanding, especially as numerous PZPR activists thought that the Church and "Solidarność" would support him. It was emphasized that, after all, Wałęsa supported Kiszczak in the presidential campaign.

Eventually, on Wałęsa's initiative, the candidature of Tadeusz Mazowiecki was proposed and immediately led to many controversies in the "Solidarnośćc circles ${ }^{2}$. Thus, the government appointed on September 2, 1989, had the first non-Communist prime minister since the war, and people previously associated with "Solidarność" had a majority in it (it should be noted here that two-state power ministries, The Ministry of Defense and the Ministry of Interior, remained in the hands of Communist ministers, Florian Siwicki, and Czesław Kiszczak, respectively).

The style of Mazowieckis ruling resulted in a deepening criticism of the round table agreement in the post- "Solidarność" circles. Already during the term of his government, as well as later, the accusations directed at the round table were repeated on multiple occasions.

1) The most important decisions were not made during the plenary negotiations or discussions at so-called sub-tables but during secret talks between selected people in a government villa in Magdalenka near Warsaw. These talks were sometimes held in conditions of excessive fraternization between the "Solidarność" and the government sides.

2) The round table talks were conducted with the "Solidarność" elites selected by the Communist security service, in some cases, with agents of the Security Service.

3) The agreement itself was a form of "a covenant between elites" (as described by Jacek Kuroń) to obtain financial and political benefits. Consequently, mixed Communist and Solidarność elites took over the power in the country, guided solely by their own interests.

2 The proposed candidates also included Bronisław Geremek, Jacek Kuroń, and Jan Olszewski proposed by the Kaczyński brothers. 
4) The contact with the Communists allowed those last ones to maintain a great influence in Special Services, state administration, various institutions, the economy, and the finances.

5) Due to the round table agreement, the Communists took a significant part of the previously state-owned industry, using the so-called "nomenclature companies".

6) Under the round table agreement, numerous terrible crimes of the Communist era were not dealt with. Among the elites, a spirit of forgiving the Communist butchers their crimes ruled, although they did not show any repentance.

7) In consequence of the round table agreement, the Security Service destroyed the major part of their files.

\section{Conclusions}

The critics of the round table are quite right in all mentioned respects. Indeed, the fraternization of certain representatives of the "Solidarność" elites with the Communists went too far. Some participants in the negotiations from the "Solidarność" side, associated with SB, played a dubious role during those talks. Some opposition activists from the leftist circles could consider the round table compromise the beginning of the new system only slightly reforming Communism. Some cynics saw only their future financial interests. Both leftists and cynic participants later played an important role in administration teams of Tadeusz Mazowiecki and Jan Krzysztof Bielecki. The round table arrangement allowed many Communists to maintain their influence in the administration and the economy. The policy of taking over the entire companies by the party dignitaries (nomenclature enfranchisement), initiated already in 1988, was continued after the round table, with the tacit consent of some former opposition activists. In consequence of the spirit of specific reconciliation with the Communists, some former "Solidarność" activists did not want to deal with the Communist crimes and gave tacit consent to the destruction of the Security Service files.

However, we must remember that the mentioned accusation does not apply to all round table participants. Many of them treated the round table agreement as a tactical movement, being only a stage in taking the entire power from the Communists. Furthermore, most negative phenomena emerged after the agreement was concluded, in consequence of a specific interpretation of the round table contract by some former opposition activists.

\section{References:}

Dudek, A. (2000). Czerwcowy przełom. Wybory 4 czerwca 1989 roku - kampania i wyniki. Więź, 6(500), 151-166.

Dudek, A. (2002). Pierwsze lata III Rzeczypospolitej 1989-2001. Arcana.

Dudek, A. (2007). Historia polityczna Polski 1989-2005. Arcana. 
Geremek, B., \& Żakowski, J. (1990). Rok 1989: Bronisław Geremek opowiada, Jacek Żakowski pyta. Plejada. Holzer, J., \& Leski, K. (1990). Solidarność w podziemiu. Wydawnictwo Łódzkie.

“Kalendarium 13 grudnia 1981 - 4 czerwca 1989”. (2000). In M. Łątkowska (Ed.), „Solidarność”. XX lat historii". Volumen.

"Lech Wałęsa dla Gazety Wyborczej”. (1989, June 23). Gazeta Wyborcza, 1.

Morawiecki, K. (1989, April 10). Po obradach okrągłego stołu. Solidarność Walcząca, 203, 1-2.

Michnik, A. (1989, June 6). Radość... i chwila namysłu. Gazeta Wyborcza, 1.

Michnik, A. (1989, July 3). Wasz Prezydent nasz premier. Gazeta Wyborcza, 1.

Polak, W. (2003). Czas ludzi niepokornych. Niezależny Samorządny Związek Zawodowy „Solidarność” i inne ugrupowania niezależne w Toruniu i Regionie Toruńskim (13 XII 1981 - 4 VI 1989). Wydawnictwo Naukowe Uniwersytetu Mikołaja Kopernika.

Przegląd Pomorski. (1989, May), 6(27).

“Przegląd prasy opozycyjnej”. (1989, May 8). Gazeta Wyborcza, 6. 